\title{
PENGARUH BRAND IMAGE DAN SIKAP KONSUMEN TERHADAP KEPUTUSAN PEMBELIAN BATIK JETIS SIDOARJO DIMEDIASI OLEH MINAT BELI
}

\author{
Muhammad Mufti Mubarok \\ Dosen STIE PERBANAS Surabaya \\ Muftimubarok99@gmail.com
}

\begin{abstract}
ABSTRAK
Dalam rangka pengembangan ekonomi daerah, maka pengembangan ekonomi lokal sesuai potensinya menjadi suatu hal yang sangat penting. Para pemilik industri batik dihadapkan pada permasalahan dalam pemasarannya. Dalam upaya mempengaruhi keputusan konsumen dalam membeli, salah satunya adalah berusaha untuk menarik minat konsumen. Citra dan sikap merupakan beberapa faktor yang harus diperhatikan para pemilik industri agar konsumen memiliki sikap positif terhadap citra dari produk itu sendiri. Tujuan dari penelitian ini adalah untuk mengetahui pengaruh brand image dan sikap konsumen terhadap keputusan pembelian secara langsung dan secara tidak langsung yang dimediasi minat beli.

Populasi dalam penelitian ini adalah konsumen batik Jetis Sidoarjo. Jumlah sampel yang digunakan dalam penelitian ini adalah 100 orang dengan menggunakan metode judgement sampling. Metode pengumpulan data menggunakan kuesioner. Analisis data menggunakan analisis jalur dengan progam IBM SPSS 21.

Penelitian ini menyimpulkan bahwa : (1) brand image berpengaruh positif dan signifikan secara langsung terhadap keputusan pembelian ; (2) sikap konsumen berpengaruh signifikan secara langsung terhadap keputusan pembelian ; (3) Brand image dan sikap konsumen berpengaruh positif dan signifikan secara tidak langsung terhadap keputusan pembelian melalui minat beli. Saran dari penelitian ini yaitu bagi para pengusaha batik di Jetis Sidoarjo, hendaknya selalu berinovasi akan produk batiknya, baik dari kombinasi motif dan warnanya. Perbaikan pada sektor tata ruang kios dan fasilitas yang memadai, menyelenggarakan event dan festival batik. Peningkatan promosi dan pemasaran melihat objek tergolong masih baru, strategi agar event batik lebih menjual dan diminati serta memiliki citra sendiri oleh para pengunjung.
\end{abstract}

Kata Kunci : Brand Image, Sikap Konsumen, Minat Beli, Keputusan Pembelian.

\section{PENDAHULUAN}

Globalisasi dan era perdagangan bebas saat ini ditandai dengan semakin meluasnya berbagai produk dan jasa, menyebabkan persaingan bisnis yang dihadapi perusahaanperusahaan semakin ketat. Dengan adanya pasar bebas, pemasaran semakin terbuka luas dan persaingan di dunia usaha semakin ketat, hal tersebut dapat dilihat dari masuknya produkproduk impor ke pasar Indonesia yang merupakan dampak dari persetujuan dan penandatangan Indonesia terhadap Asean-Cina Free Trade Area (ACFTA). Dengan adanya persetujuan tersebut, produk impor bebas masuk ke pasar Indonesia. Para pemasar dituntut 
untuk lebih cermat menyikapi dalam menentukan strategi bersaing dan memanfaatkan peluang yang ada. Pemasar dituntut untuk kreatif dan inovatif agar dapat menarik perhatian konsumen dan membawa minat dari konsumen untuk membeli produk yang ditawarkan.

Perusahaan menggunakan berbagai media dalam memasarkan produknya, salah satunya adalah sebagai upaya untuk memberikan citra yang baik terhadap konsumen. Citra merek merupakan interprestasi akumulasi berbagai informasi yang diterima konsumen (Simamora \& Lim, 2002) dalam Arista (2011:5). Citra dari perusahaan yang baik juga tak lepas dari pandangan konsumen terhadap apa yang perusahaan berikan dan apa yang konsumen rasakan. Menurut Kotler (2005) yang menginterpretasi adalah konsumen dan yang diinterpretasikan adalah informasi. Informasi citra dapat dilihat dari logo atau simbol yang digunakan oleh perusahaan untuk mewakili produknya, di mana simbol dan logo ini bukan hanya sebagai pembeda dari para pesaing sejenis namun juga dapat merefleksikan mutu dan visi misi perusahaan tersebut. Citra inilah yang digunakan perusahaan dalam menarik minat konsumen dengan berusaha memberikan informasi yang nantinya akan diinterprestasikan, konsumen yang bersikap positif terhadap produk cenderung memiliki keinginan kuat untuk memilih dan membeli produk yang disukai tersebut (Suryani, 2008:160).

Sikap konsumen terbentuk dari kecenderungan konsumen melakukan sesuatu tindakan terhadap obyek, tindakan konsumen tersebut untuk menilai suatu obyek yang diminatinya untuk dimiliki. Sikap sebagai suatu evaluasi yang menyeluruh dan memungkinkan seseorang untuk merespon dengan cara yang menguntungkan atau tidak terhadap obyek yang dinilai. Konsumen yang telah memiliki sikap positif terhadap suatu produk atau merek, akan menimbulkan minat pembelian terhadap produk atau merek tersebut. Bhaduri (2011:11) berpendapat bahwa minat memainkan suatu peran penting dalam menentukan bagaimana orang berperilaku. Istilah minat beli memiliki makna tujuan dan umumnya digunakan untuk memahami tujuan konsumen dalam membuat suatu keputusan pembelian. Semakin baik citra dari produk atau merek, akan meningkatkan keputusan konsumen untuk melakukan pembelian terhadap suatu produk atau merek tersebut.

Minat sebagai dorongan, yaitu rangsangan internal yang kuat yang memotivasi tindakan, dimana dorongan ini dipengaruhi oleh stimulus dan perasaan positif akan produk (Kotler, 2006:165) dalam Mahendrayasa (2014:2).

Jika rangsangan yang di lakukan kuat dan positif maka akan mendorong konsumen dan meningkatkan minat beli mereka, sebaliknya jika rangsangan atau dorongan yang di lakukan lemah dan kurang mengena perasaan konsumen maka minat beli mereka pun lemah. Jika rangsangan atau dorongan yang di berikan melebihi ekspektasi maka konsumen akan bisa 
menerima perasaan positif atau menyenangkan sehingga memiliki minat beli yang lebih kuat dan dampaknya muncul keputusan untuk membeli di bandingkan jika minat beli yang lemah konsumen akan melakukan pemilihan alternatif lain sebelum melakukan keputusan pembelian.

Keputusan pembelian dapat didefinisikan sebagai suatu proses di mana konsumen melakukan penilaian terhadap berbagai alternatif pilihan dan memilih salah satu atau lebih alternatif yang diperlukan berdasarkan pertimbangan-pertimbangan tertentu. Keputusan pembelian yang dilakukan oleh konsumen menggambarkan seberapa jauh tingkat pengaruh usaha pemasaran yang dilakukan terhadap suatu produk sehingga pemasar harus mengetahui perilaku konsumen dalam hal menentukan keputusan pembeliannya.

Tujuan penelitian ini untuk mengetahui pengaruh brand image dan sikap konsumen terhadap keputusan pembelian yang dimediasi oleh minat beli batik Jetis Sidoarjo.

\section{TINJAUAN PUSTAKA DAN PENGEMBANGAN HIPOTESIS}

\subsection{Brand Image}

Setiadi (2003:180) mengemukakan Citra merek mengacu pada skemamemori akan sebuah merek, yang berisikan interpretasi konsumen atas atribut,kelebihan, penggunaan, situasi, para pengguna, dan karakteristik pemasardan/atau karakteristik pembuat dari produk/merek tersebut. Citra merek adalahapa yang konsumen pikirkan dan rasakan ketika mendengar atau melihat namasuatu merek. Menurut Kotler (2005) mengatakan yang menginterpretasi adalah konsumen dan yang diinterpretasikan adalah informasi. Informasi citra dapat dilihat dari logo atau simbol yang digunakan oleh perusahaan untuk mewakili produknya, di mana simbol dan logo ini bukan hanya sebagai pembeda dari para pesaing sejenis namun juga dapat merefleksikan mutu dan visi misi perusahaan tersebut.

Berdasarkan uraian diatas dapat disimpulkan bahwa citra merek (brand image) adalah serangkaian deskripsi tentang asosiasi dan keyakinan konsumen terhadap merek tertentu. Brand image dari suatu produk yang positif akan mendorong konsumen melakukan pembelian produk tersebut daripada membeli produk yang sama dengan merek lain. Selain hal tersebut, logo dan iklan juga memegang peranan penting untuk menciptakan sebuah citra merek. Citra merek yang dibangun dapat menjadi identitas dan cerminan dari visi, kesunggulan,standar kualitas, pelayanan dan komitmen dari pelaku usaha atau pemiliknya. Karena itu penting bagi perusahaan untuk memperhatikan perilaku pembelian mereka guna menentukan langkah ke depan yang akan diambil tepat untuk mengantisipasinya. 


\section{Pengukuran Brand Image}

Menurut Shimp (2003: 592) dalam Rizan (2012:5), ada tiga bagian yang terdapat dalam pengukuran citra merek. Bagian pertama adalah atribut. Atribut adalah ciri-ciri atau berbagai aspek dari merek yang diiklankan. Atribut juga dibagi menjadi dua bagian yaitu halhal yang tidak berhubungan dengan produk (contoh: harga, kemasan, pemakai, dan citra penggunaan), dan hal-hal yang berhubungan dengan produk (contoh: warna, ukuran, desain). Kemudian bagian kedua pengukuran citra merek menurut Shimp adalah manfaat. Manfaat dibagi menjadi tiga bagian yaitu :

1. Fungsional, yaitu manfaat yang berusaha menyediakan solusi bagi masalah-masalah konsumsi atau potensi permasalahan yang dapat dialami oleh konsumen.

2. Simbolis, yaitu diarahkan pada keinginan konsumen dalam upaya memperbaiki diri, dihargai sebagai anggota suatu kelompok, afiliasi, dan rasa memiliki.

3. Pengalaman, yaitu konsumen merupakan representasi dari keinginan mereka akan produk yang dapat memberikan rasa senang, keanekaragaman, dan stimulasi kognitif.

\section{Pembentukan Brand Image}

Menurut Durianto dalam Amanah (2011:226), pembentukan citra disebut positioning. Merek yang berhasil adalah merek yang memiliki posisi yang kuat. Agar posisi merek kuat, merek tersebut harus dikenal terlebih dahulu. Pengenalan merek menjadi landasan terbentuknya asosiasi merek. Berbagai asosiasi merek yang berhubungan akan menimbulkan suatu rangkaian yang disebut citra merek. Citra terhadap suatu merek berhubungan dengan sikap yang berhubungan dengan keyakinan dan persepsi terhadap suatu merek. Semakin banyak asosiasi yang saling berhubungan, semakin kuat citra yang dimiliki oleh merek tersebut. Asosiasi-asosiasi yang terkait dengan suatu merek mengacu pada berbagai hal, yaitu

1. Atribut produk

2. Atribut tak berwujud

3. Manfaat bagi konsumen

4. Harga relatif

5. Penggunaan

6. Konsumen

\subsection{Perilaku Konsumen}

Kotler dan Keller (2008) mendefinisikan perilaku konsumen adalah studi bagaimana individu, kelompok dan organisasi memilih, membeli, menggunakan dan menempatkan barang, jasa, ide atau pengalaman untuk memuaskan keinginan dan kebutuhan mereka. 
Schiffman dan Kanuk (2010) mendefinisikan perilaku konsumen diartikan sebagai prilaku yang diperlihatkan konsumen dalam mencari, membeli, menggunakan, mengevaluasi dan menghabiskan produk dan jasa yang mereka harapkan akan memuaskan kebutuhan mereka.

Perilaku konsumen merupakan tindakan yang langsung terlibat dalam mendapatkan, mengkonsumsi, dan menghabiskan produk dan jasa, termasuk keputusan yang mendahului dan mengikuti tindakan ini (Engel, Blackwell dan Miniard (1995) dalam Sumarwan (2011:4)

Sumarwan (2011) menyatakan prilaku konsumen adalah semua kegiatan, tindakan serta proses psikologis yang mendorong tidakan tersebut pada saat sebelum membeli, ketika membeli, menggunakan, menghabiskan produk dan jasa setelah melakukan hal-hal diatas atau kegiatan mengevaluasi.

Berdasarkan uraian yang telah disebutkan di atas dapat disimpulkan bahwa perilaku konsumen adalah semua kegiatan, tindakan, serta proses psikologis yang mendorong tindakan tersebut pada saat sebelum dan sesudah menggunakan, perilaku yang ditunjukkan konsumen dalam menyelidiki, membeli, menggunakan, mengevaluasi dan menentukan produk atau jasa dan ide, di mana akhirnya mereka akan mendapat kepuasan atau ketidakpuasan pasca menggunakan produk atau jasa terhadap kebutuhan mereka.

\subsection{Sikap Konsumen}

Sikap merupakan evaluasi, perasaan emosional, dan kecenderungan tindakan yang menguntungkan atau tidak menguntungkan dan bertahan lama dari seseorang terhadap suatu obyek atau gagasan (Kotler dan Keller 2008).

Menurut pendapat Schiffman dan Kanuk dalam Sumarwan (2011:166) dalam konteks perilaku konsumen, "Sikap adalah kecenderungan yang dipelajari dalam berperilaku dengan cara yang menyenangkan atau tidak menyenangkan terhadap suatu obyek tertentu”.

Berdasarkan uraian yang telah disebutkan diatas dapat disimpulkan bahwa sikap sebagai mekanisme mental yang mengevaluasi, membentuk pandangan dan emosional yang di pelajari menentukan perilaku atau individu terhadap suatu obyek tertentu.

\section{Fungsi Sikap Konsumen}

Daniel Kazt dalam Sumarwan (2011:168) mengklasifikasikan empat fungsi sikap yaitu

\section{Fungsi Utilitarian (The Utilitarian Function)}

Seseorang menyatakan sikapnya terhadap suatu objek atau produk karena ingin memperoleh manfaat dari produk (rewards) tersebut atau menghindari resiko dari produk (punishment).

2. Fungsi Mempertahankan Ego (The Ego-Defensive Function) 
Sikap berfungsi untuk melindungi seseorang (citra diri-self images) dari keraguan yang muncul dari dalam dirinya sendiriatau dari faktor luar yang mungkin menjadi ancaman bagi dirinya.

3. Fungsi Ekspresi Nilai (The Value-Expressive Function)

Sikap berfungsi untuk menyatakan nilai-nilai, gaya hidup dan identitas sosial dari seseorang. Sikap akan menggambarkan minat, hobi, kegiatan dan opini dari seorang konsumen.

4. Fungsi Pengetahuan (The Knowledge Function)

Keingintahuan adalah salah satu karakter konsumen yang penting. Ia selalu ingin tahu banyak hal, merupakan kebutuhan konsumen. Sering kali konsumen perlu tahu produk terlebih dahulu sebelum ia menyukai kemudian membeli produk tersebut.

\section{Faktor-Faktor Yang Mempengaruhi Pembentukan Sikap}

Sikap terbentuk melalui pembelajaran yang dilakukan oleh individu. Oleh karena itu, terbentuknya sikap tidak terlepas dari lingkungan dimana konsumen melakukan pembelajaran. Menurut Suryani (2008 : 175) faktor-faktor yang berperan penting dalam pembentukan sikap, yaitu :

1. Pengalaman langsung

2. Pengaruh keluarga

3. Teman sebaya

4. Pemasaran langsung

5. Tayangan media masa

\subsection{Minat Beli}

Minat beli diperoleh dari suatu proses belajar dan proses pemikiran yang membentuk suatu persepsi. Minat beli ini menciptakan suatu motivasi yang terus terekam dalam benaknya dan menjadi suatu keinginan yang sangat kuat yang pada akhirnya ketika seorang konsumen harus memenuhi kebutuhannya akan mengaktualisasikan apa yang ada didalam benaknya itu. Menurut Keller (1998), minat konsumen adalah seberapa besar kemungkinan konsumen membeli suatu merek atau seberapa besar kemungkinan konsumen untuk berpindah dari satu merek ke merek lainnya.Schiffman dan Kanuk (2010:201) dalam Febiana (2014:3) menyatakan bahwa minat merupakan salah satu aspek psikologis yang memiliki pengaruh cukup besar terhadap sikap perilaku. Penilaian konsumen terhadap produk tergantung pada 
pengetahuannya akan informasi tentang fungsi sebenarnya dari produk tersebut, dengan demikian konsumen yang berminat untuk melakukan pembelian suatu produk dipengaruhi oleh informasi yang diterima.

Berdasarkan uraian di atas dapat disimpulkan bahwa minat beli muncul karena adanya proses belajar yang menciptakan suatu motivasi pada diri konsumen untuk memenuhi kebutuhanya dan merupakan aspek psikologis yang berpengaruh terhadap sikap dan prilaku konsumen untuk membeli suatu produk yang dipengaruhi oleh informasi yang diterimanya.

\section{Faktor Pembentuk Minat Beli}

Beberapa faktor yang membentuk minat beli konsumen (Kotler, 2005) :

1. Sikap orang lain, sejauh mana sikap orang lain mengurangi alternatif yang disukai seseorang akan bergantung pada dua hal yaitu, intensitas sifat negatif orang lain terhadap alternatif yang disukai konsumen dan motivasi konsumen untuk menuruti keinginan orang lain.

2. Faktor situasi yang tidak terantisipasi, faktor ini nantinya akan dapat mengubah pendirian konsumen dalam melakukan pembelian. Hal tersebut tergantung dari pemikiran konsumen sendiri, apakah dia percaya diri dalam memutuskan akan membeli suatu barang atau tidak.

Swastha dan Irawan (2005:349) dalam Febiana (2014:3) mengemukakan faktor-faktor yang mempengaruhi minat membeli berhubungan dengan perasaan emosi, bila seseorang merasa senang dan puas dalam membeli barang atau jasa maka hal itu akan memperkuat minat membeli, kegagalan biasanya menghilangkan minat. Tidak ada pembelian yang terjadi jika konsumen tidak pernah menyadari kebutuhan dan keinginannya. Pengenalan masalah (problem recognition) terjadi ketika konsumen meilhat adanya perbedaan yang signifikan antara apa yang dia miliki dengan apa yang dia butuhkan.

Lucas dan Britt (2003) dalam Mardiastika (2012:15) mengatakan bahwa aspek-aspek yang terdapat dalam minat beli antara lain :

1. Perhatian, adanya perhatian yang besar dari konsumen terhadap suatu produk (barang atau jasa).

2. Ketertarikan, setelah adanya perhatian maka akan timbul rasa tertarik pada konsumen.

3. Keinginan, berlanjut pada perasaan untuk mengingini atau memiliki suatu produk tersebut.

4. Keyakinan, kemudian timbul keyakinan pada diri individu terhadap produk tersebut sehingga menimbulkan keputusan (proses akhir) untuk memperolehnya dengan tindakan yang disebut membeli. 
5. Keputusan, disimpulkan bahwa aspek-aspek dalam minat beli yaitu ketertarikan, keinginan dan keyakinan.

Faktor-faktor yang mempengaruhi minat membeli berhubungan dengan perasaan dan emosi, bila seseorang merasa senang dan puas dalam membeli barang atau jasa maka hal itu akan memperkuat minat membeli, ketidakpuasan biasanya menghilangkan minat. Super dan Crites (1998) dalam Mardiastika (2012:17) menjelaskan bahwa ada beberapa faktor yang mempengaruhi minat, yaitu :

1. Perbedaan pekerjaan

2. Perbedaan sosial ekonomi

3. Perbedaan hobi atau kegemaran

4. Perbedaan jenis kelamin

5. Perbedaan usia

\subsection{Keputusan Pembelian}

Sebuah keputusan secara umum merupakan seleksi terhadap dua pilihan alternatif atau lebih. Pilihan tersebut dapat mengenai pilihan merek, waktu, distribusi, dan lain-lain (Schiffman dan Kanuk, 2010:485). Kotler dan Armstrong (2008:129) menerjemahkan keputusan pembelian sebagai sebuah proses dimana konsumen mengenal masalahnya, mencari informasi mengenai produk atau merek tertentu dan mengevaluasi seberapa baik masing-masing alternatif tersebut dapat memecahkan masalahnya yang kemudian mengarah kepada keputusan pembelian. Menurut Kotler dan Armstrong (2008:181), keputusan pembelian konsumen adalah membeli merek yang paling disukai dari berbagai alternatif yang ada, tetapi dua faktor bisa berada antara niat pembelian dan keputusan pembelian. Faktor pertama adalah sikap orang lain dan faktor yang kedua adalah faktor situasional. Oleh karena itu, preferensi dan niat pembelian tidak selalu menghasilkan pembelian yang aktual.

Pengambilan keputusan merupakan suatu kegiatan individu yang secara langsung terlibat dalam mendapatkan dan mempergunakan barang yang ditawarkan. Menurut Setiadi (2003:341), mendefinisikan suatu keputusan (decision) melibatkan pilihan diantara dua atau lebih alternatif tindakan atau perilaku. Keputusan selalu mensyaratkan pilihan diantara beberapa perilaku yang berbeda.

Berdasarkan uraian di atas dapat disimpulkan bahwa keputusan pembelian merupakan tindakan yang dilakukan konsumen dalam melakukan pembelian sebuah produk atau tindakan pemecahan masalah yang dilakukan individu dalam pemilihan alternatif dari beberapa alternatif penyelesaian masalah berdasarkan pengetahuan yang dimiliki konsumen.

Faktor-faktor yang Mempengaruhi Keputusan Konsumen 
Setiadi (2003:425-231) berpendapat bahwa faktor-faktor yang mempengaruhi keputusan pembelian meliputi :

1. Tujuan Konsumen

2. Hierarki Tujuan Konsumen

3. Keterlibatan dan Pengetahuan Konsumen

4. Lingkungan

\section{Tingkat Pengambilan Keputusan Konsumen}

Tidak semua situasi pengambilan keputusan konsumen menerima (atau membutuhkan) tingkat pencarian informasi yang sama. Jika semua keputusan pembelian membutuhkan usaha yang besar, usaha pengambilan keputusan konsumen akan melelahkan dan menyita waktu. Sebaliknya, jika semua pembelian sudah merupakan hal rutin, maka akan cenderung membosankan dan hanya sedikit memberikan kesenangan atau sesuatu yang baru. Dalam rangkaian usaha yang berkisar paling tinggi sampai rendah, dapat dibedakan tingkat pengambilan keputusan konsumen sebagai berikut (Schiffman dan Kanuk, 2010:487) :

1. Pemecahan Masalah yang Luas

2. Pemecahan Masalah yang Terbatas

3. Perilaku Sebagai Respon yang Rutin

\subsection{Pengembangan Hipotesis}

\subsubsection{Pengaruh Brand Image Terhadap Minat Beli}

Shah (2012:5) yang meneliti mengenai pengaruh brand image terhadap minat beli menjelaskan bahwa brand image memiliki pengaruh positif terhadap minat beli konsumen, menyebutkan bahwa semakin positif brand image semakin tinggi minat beli dan menyimpulkan bahwa konsumen dalam penelitian ini perokok memperhatikan brand image untuk menarik minat beli mereka.

Arista (2011:6) yang meneliti mengenai pengaruh citra merek terhadap minat beli produk Telkom Speedy menyimpulkan bahwa citra merek tidak memiliki pengaruh signifikan terhadap minat beli. Konsumen tidak memilih citra merek sebagai variabel yang mendukung minat beli karena konsumen lebih mempercayai konsumen lain tentang keunggulan dan kehandalan yang telah menggunakan Telkom Speedy sehingga konsumen lebih memutuskan menggunakan Telkom Speedy berdasarkan pengalaman dari konsumen lain yang telah menggunakan Telkom Speedy terlebih dahulu

Berdasarkan kedua penelitian di atas dapat dibuat hipotesis penelitian yaitu : 
H1 : Brand image berpengaruh positif terhadap minat beli

\subsubsection{Pengaruh Sikap Konsumen Terhadap Minat Beli}

Chen (2011:4) yang meneliti mengenai pengaruh sikap konsumen terhadap minat beli dan menyimpulkan bahwa minat beli di pengaruhi oleh sikap konsumen, maka semakin positif sikap konsumen semakin tinggi minat beli konsumen.

Berdasarkan penelitian di atas dapat dibuat hipotesis penelitian yaitu :

$\mathrm{H} 2$ : sikap konsumen berpengaruh positif terhadap minat beli

\subsubsection{Pengaruh Brand Image Terhadap Keputusan Pembelian}

Mendrofa (2010:4) yang meneliti mengenai pengaruh brand image pada keputusan pembelian menjelaskan bahwa brand image mempunyai pengaruh positif dan signifikan pada keinginan konsumen untuk membeli laptop merek HP, menyimpulkan bahwa brand image memiliki pengaruh positif terhadap keputusan pembelian. Pengaruh yang positif bisa diartikan bahwa semakin positif brand image maka semakin tinggi intensitas pembelian konsumen pada pembelian laptop merek HP.

Saeed et al (2013:5) yang meneliti faktor yang mempengaruhi keputusan pembelian pada industri pakaian di Sahiwal, Pakistan menyebutkan bahwa brand image tidak memilik pengaruh yang signifikan terhadap keputusan pembelian konsumen dan menyimpulkan bahwa konsumen di Sahiwal tidak memperhatikan brand image dalam membeli produk pakaian.

Berdasarkan kedua penelitian di atas dapat dibuat hipotesis penelitian yaitu :

$\mathrm{H} 3$ : brand image berpengaruh positif terhadap keputusan pembelian

\subsubsection{Pengaruh Sikap Konsumen Terhadap Keputusan Pembelian}

Lendo (2013:5) yang meneliti mengenai pengaruh sikap konsumen terhadap keputusan pembelian pada online shop menyimpulkan bahwa sikap konsumen memiliki pengaruh positif terhadap keputusan pembelian, artinya bahwa semakin positif sikap konsumen maka semakin tinggi pembelian konsumen pada online shop.

Utami (2010:7) mengatakan bahwa sikap konsumen tidak berpengaruh terhadap keputusan pembelian dan menyimpulkan bahwa keputusan pembelian susu formula tidak di pengaruhi oleh sikap konsumen.

Berdasarkan kedua penelitian di atas dapat dibuat hipotesis penelitian yaitu : H4 : sikap konsumen berpengaruh positif terhadap keputusan pembelian

\subsubsection{Pengaruh Minat Beli Terhadap Keputusan Pembelian}


Mahendrayasa (2014:4) yang meneliti mengenai pengaruh minat beli terhadap keputusan pembelian kartu GSM menyimpulkan bahwa minat beli memiliki pengaruh yang positif dan signifikan terhadap keputusan pembelian. Artinya semakin positif minat beli, semakin tinggi keputusan pembelian kartu GSM.

Sedangkan Penelitian Montjai (2014:9) mengemukakan bahwa minat beli konsumen tidak berpengaruh signifikan terhadap keputusan pembelian sepeda motor. Menyimpulkan bahwa konsumen di Manado tidak memperhatikan minat beli dalam membeli sepeda motor.

Berdasarkan kedua penelitian di atas dapat dibuat hipotesis penelitian yaitu :

H5 : minat beli berpengaruh positif terhadap keputusan pembelian

Berdasarkan landasan teori yang dikemukakan, berikut disajikan kerangka pemikiran teoritis yang dituangkan dalam model penelitian seperti yang ditunjukkan pada gambar berikut ini :

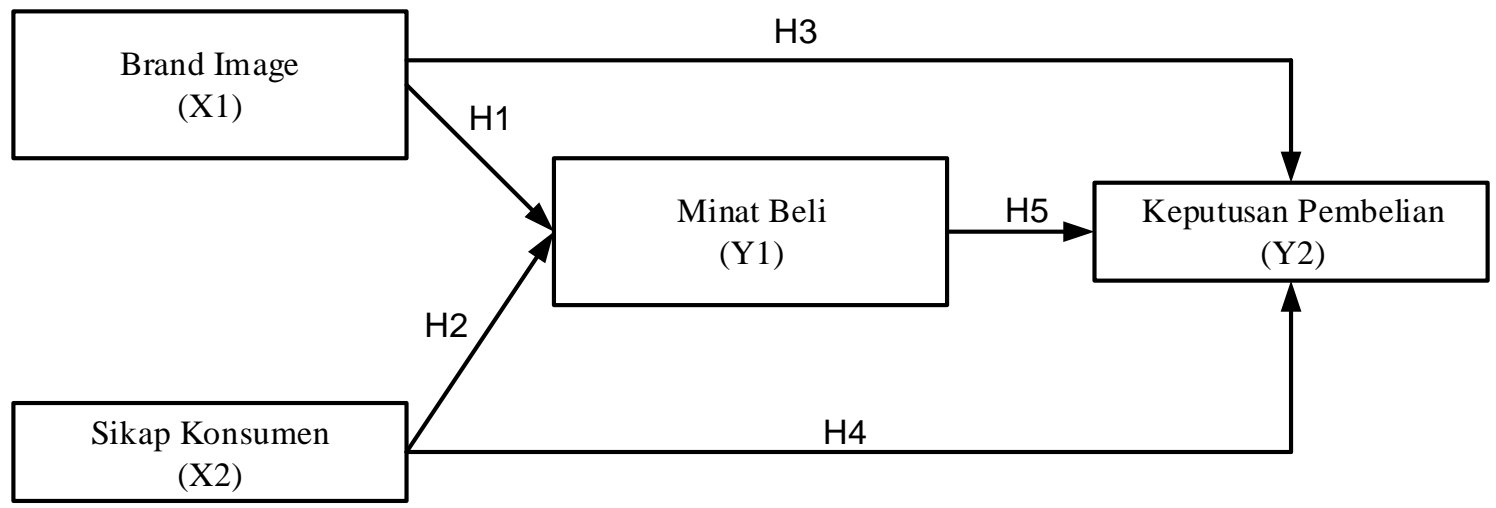

Gambar 1. Model Penelitian dan Hipotesis

\section{METODE PENELITIAN}

\subsection{Populasi dan Sampel}

Populasi adalah sekelompok elemen yang lengkap, yang biasanya berupa orang, objek atau kejadian dimana kita tertarik untuk mempelajari suatu objek penelitian (Kuncoro, 2009:103). Populasi dalam penelitian ini adalah konsumen yang pernah membeli Batik Jetis selama bulan Agustus dan September 2016.

Teknik pengambilan sampel yang digunakan dalam penelitian ini adalah nonprobability sample yang artinya desain sampel dimana sampel dikumpulkan dengan suatu proses dimana individu dalam populasi tidak diberikan kesempatan yang sama untuk dipilih 
sebagai sampel. Peneliti menggunakan teknik nonprobability sample karena peneliti tidak mengetahui jumlah populasi dari konsumen yang berbelanja online untuk dijadikan sebagai sampel. Dalam penelitian ini, teknik nonprobability sample yang dipakai adalah judgement sampling. Judgement sampling adalah sampel yang dipilih berdasarkan penilaian peneliti bahwa 100 konsumen pernah membeli Batik Jetis minimal total pembelanjaan 200.000 rupiah.

\subsection{Definisi Operasional Variabel}

\section{Brand Image}

Serangkaian deskripsi tentang asosiasi dan keyakinan konsumen terhadap merek tertentu. Indikatornya adalah : Quality, Awareness, Kepribadian dan Citra Diri (Iwan2013)

\section{Sikap Konsumen}

Mekanisme mental yang mengevaluasi, membentuk pandangan dan emosional yang di pelajari menentukan perilaku atau individu terhadap suatu obyek tertentu. Indikator yang digunakan adalah : kognitif, Afektif dan konatif (Sumarwan, 2011).

\section{Minat Beli}

Minat beli diperoleh dari suatu proses belajar dan proses pemikiran yang membentuk suatu persepsi. Minat beli ini menciptakan suatu motivasi yang terus terekam dalam benaknya dan menjadi suatu keinginan yang sangat kuat yang pada akhirnya ketika seorang konsumen harus memenuhi kebutuhannya akan mengaktualisasikan apa yang ada didalam benaknya itu. Indikator yang digunakan adalah minat transaksional, minat preferensial dan minat eksploratif (Ferdinand, 2011).

\section{Keputusan Pembelian}

Suatu keputusan (decision) melibatkan pilihan diantara dua atau lebih alternatif tindakan atau perilaku. Keputusan selalu mensyaratkan pilihan diantara beberapa perilaku yang berbeda. Indokator yang digunakan adalah : pilihan produk, pilihan penyalur, pilihan waktu dan pilihan merek (Kotler Keller, 2006).

\subsection{Teknik Analisis}

\section{Uji Validitas}

Uji validitas dilakukan untuk mengukur apakah data yang didapat setelah penelitian merupakan data yang valid dengan alat ukur yang digunakan (kuesioner). Metode yang digunakan adalah dengan membandingkan antara nilai korelasi atau $r$ hitung dari variabel penelitian dengan nilai $r$ tabel. Pengujian validitas dalam penelitian ini menggunakan bantuan 
software SPSS (Statistic Package and Social Science) versi 21.0 for windows (Ghozali, 2013).

a. Jika nilai $r_{\text {hitung }}>r_{\text {tabel }}$ maka pernyataan dinyatakan valid.

b. Jika nilai $r_{\text {hitung }}<r_{\text {tabel }}$ maka pernyataan dinyatakan tidak valid.

\section{Uji Reliabilitas}

Uji reliabilitas digunakan untuk melihat apakah alat ukur yang digunakan menunjukkan konsistensi di dalam mengukur gejala yang sama. Pengujian reliabilitas dalam penelitian ini menggunakan bantuan software SPSS (Statistic Package and Social Science) versi 21.0 for windows. Pertanyaan yang telah dinyatakan valid dalam uji validitas, maka akan ditentukan reliabilitasnya dengan kriteria sebagai berikut : (Ghozali, 2013).

a. Jika nilai Cronbach's Alpha > 0,60 maka pernyataan reliabel.

b. Jika nilai Cronbach's Alpha $<0,60$ maka pernyataan tidak reliabel

\section{Analisis Jalur}

Analisis jalur bertujuan untuk mengidentifikasikan jalur penyebab suatu variabel tertentu terhadap variabel lain yang dipengaruhinya (Sarwono, 2012:18). Dalam model hubungan antar variabel tersebut, terdapat variabel independen yang dalam hal ini disebut variabel eksogen dan variabel dependen yang disebut variabel endogen. Variabel eksogen adalah sikap konsumen dan brand image. Variabel endogen minat beli dan keputusan pembelian.

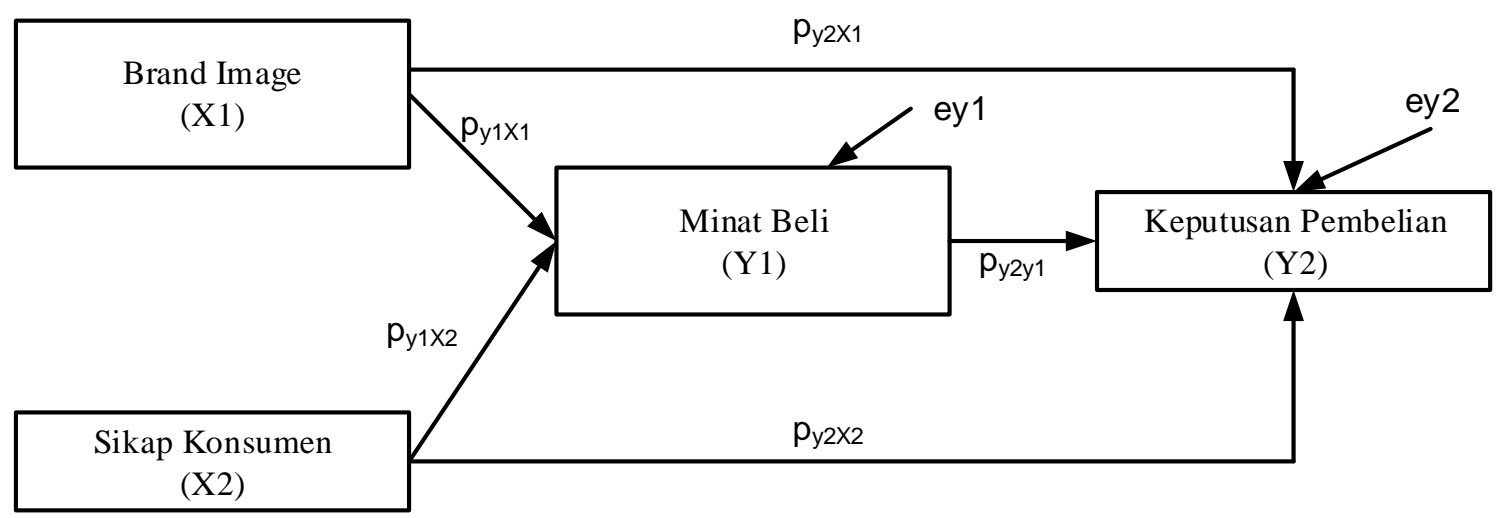

Gambar 2. Model Analisis Jalur

Persamaan jalur berdasarkan gambar diatas adalah :

$\mathrm{Y} 1=\mathrm{p}_{\mathrm{y} 1 \times 1} \mathrm{X} 1+\mathrm{p}_{\mathrm{y} 1 \mathrm{x} 2} \mathrm{X} 2+\mathrm{e}_{\mathrm{y} 1}$

$\mathrm{Y} 2=\mathrm{p}_{\mathrm{y} 2 \mathrm{x} 1} \mathrm{X} 1+\mathrm{p}_{\mathrm{y} 2 \mathrm{x} 2} \mathrm{X} 2+\mathrm{p}_{\mathrm{y} 2 \mathrm{y} 1} \mathrm{Y} 2+\mathrm{e}_{\mathrm{y} 2}$

\section{HASIL ANALISIS}

\subsection{Uji Validitas dan Reliabilitas}

Hasil uji Validitas brand image (12 item) dapat dilihat pada tabel 3.1 sebagai berikut : 
Tabel 3.1 Uji Validitas Brand Image

\begin{tabular}{|c|c|c|c|}
\hline No & rxy & r tabel & Kriteria \\
\hline 1 & 0,787 & 0,361 & Valid \\
\hline 2 & 0,573 & 0,361 & Valid \\
\hline 3 & 0,480 & 0,361 & Valid \\
\hline 4 & 0,529 & 0,361 & Valid \\
\hline 5 & 0,655 & 0,361 & Valid \\
\hline 6 & 0,487 & 0,361 & Valid \\
\hline 7 & 0,676 & 0,361 & Valid \\
\hline 8 & 0,510 & 0,361 & Valid \\
\hline 9 & 0,561 & 0,361 & Valid \\
\hline 10 & 0,541 & 0,361 & Valid \\
\hline 11 & 0,676 & 0,361 & Valid \\
\hline 12 & 0,625 & 0,361 & Valid \\
\hline
\end{tabular}

Berdasarkan tabel 3.1 terlihat bahwa semua butir pertanyaan yang digunakan untuk mengukur variabel Brand Image mempunyai $\mathrm{r}$ hitung > 0,361. Hal ini menunjukkan keduabelas item pertanyaan untuk mengukur brand image valid.

Hasil uji Validitas sikap konsumen (9 item) dapat dilihat pada tabel 3.2 sebagai berikut :

Tabel 3.2 Uji Validitas sikap konsumen

\begin{tabular}{|c|c|c|c|}
\hline No & rxy & r tabel & Kriteria \\
\hline 1 & 0,490 & 0,361 & Valid \\
\hline 2 & 0,695 & 0,361 & Valid \\
\hline 3 & 0,764 & 0,361 & Valid \\
\hline 4 & 0,697 & 0,361 & Valid \\
\hline 5 & 0,689 & 0,361 & Valid \\
\hline 6 & 0,362 & 0,361 & Valid \\
\hline 7 & 0,653 & 0,361 & Valid \\
\hline 8 & 0,441 & 0,361 & Valid \\
\hline 9 & 0,544 & 0,361 & Valid \\
\hline
\end{tabular}

Berdasarkan tabel 3.2 terlihat bahwa semua butir pertanyaan yang digunakan untuk mengukur variabel sikap konsumen mempunyai $\mathrm{r}$ hitung $>0,361$. Hal ini menunjukkan sembilan item pertanyaan untuk mengukur sikap konsumen valid.

Hasil uji Validitas minat beli (12 item) dapat dilihat pada tabel 3.3 sebagai berikut :

Tabel 3.3 Uji Validitas sikap konsumen

\begin{tabular}{|c|c|c|c|}
\hline No & rxy & r tabel & Kriteria \\
\hline 1 & 0,402 & 0,361 & Valid \\
\hline 2 & 0,510 & 0,361 & Valid \\
\hline 3 & 0,512 & 0,361 & Valid \\
\hline 4 & 0,659 & 0,361 & Valid \\
\hline 5 & 0,439 & 0,361 & Valid \\
\hline 6 & 0,524 & 0,361 & Valid \\
\hline
\end{tabular}




\begin{tabular}{|c|c|c|c|}
\hline 7 & 0,460 & 0,361 & Valid \\
\hline 8 & 0,374 & 0,361 & Valid \\
\hline 9 & 0,395 & 0,361 & Valid \\
\hline 10 & 0,534 & 0,361 & Valid \\
\hline 11 & 0,681 & 0,361 & Valid \\
\hline 12 & 0,422 & 0,361 & Valid \\
\hline
\end{tabular}

Berdasarkan tabel 3.3 terlihat bahwa semua butir pertanyaan yang digunakan untuk mengukur variabel sikap konsumen mempunyai $r$ hitung $>0,361$. Hal ini menunjukkan duabelas item pertanyaan untuk mengukur sikap konsumen valid.

Hasil uji Validitas minat beli (10 item) dapat dilihat pada tabel 3.4 sebagai berikut :

Tabel 3.4 Uji Validitas minat beli

\begin{tabular}{|c|c|c|c|}
\hline No & rxy & r tabel & Kriteria \\
\hline 1 & 0,573 & 0,361 & Valid \\
\hline 2 & 0,442 & 0,361 & Valid \\
\hline 3 & 0,469 & 0,361 & Valid \\
\hline 4 & 0,621 & 0,361 & Valid \\
\hline 5 & 0,795 & 0,361 & Valid \\
\hline 6 & 0,419 & 0,361 & Valid \\
\hline 7 & 0,533 & 0,361 & Valid \\
\hline 8 & 0,394 & 0,361 & Valid \\
\hline 9 & 0,455 & 0,361 & Valid \\
\hline 10 & 0,493 & 0,361 & Valid \\
\hline
\end{tabular}

Berdasarkan tabel 3.4 terlihat bahwa semua butir pertanyaan yang digunakan untuk mengukur variabel minat beli mempunyai $\mathrm{r}$ hitung $>0,361$. Hal ini menunjukkan sepuluh item pertanyaan untuk mengukur minat beli valid.

Tabel 3.5 Uji reliabilitas Instrumen

\begin{tabular}{|c|l|c|c|c|}
\hline No. & \multicolumn{1}{|c|}{ Variabel } & $\begin{array}{c}\text { Cronbach's } \\
\text { Alpha }\end{array}$ & $\begin{array}{c}\text { Cronbach's } \\
\text { Alpha yang disyaratkan }\end{array}$ & Kriteria \\
\hline 1 & Brand Image & 0,729 & 0,70 & Reliabel \\
\hline 2 & Sikap Konsumen & 0,761 & 0,70 & Reliabel \\
\hline 3 & Minat Beli & 0,715 & 0,70 & Reliabel \\
\hline 4 & Keputusan Pembelian & 0,736 & 0,70 & Reliabel \\
\hline
\end{tabular}

Berdasarkan tabel 3.6 menunjukan bahwa nilai Cronbach's Alphainstrumen untuk semua variabel penelitian mempunyai Cronbach's Alpha > 0,70, sehingga dapat dikatakan bahwa instrumen dalam penelitian ini adalah reliabel dan layak digunakan untuk pengumpulan dan penelitian.

\subsection{Hasil Analisis Jalur}




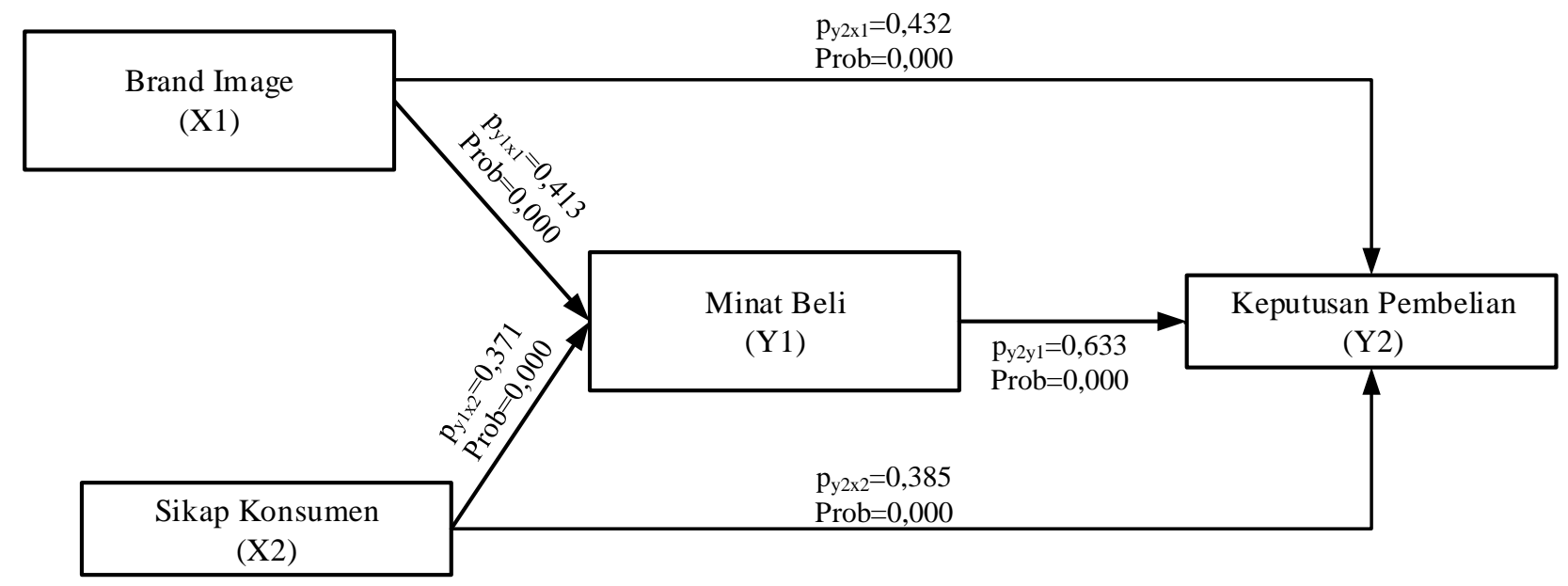

Gambar 4. Hasil Analisis Jalur

Berdasarkan Gambar di atas diperoleh persamaan jalur sebagai berikut :

1. $\mathrm{Y} 1=0,413 \mathrm{X} 1+0,371 \mathrm{X} 2$

2. $\mathrm{Y} 2=0,432 \mathrm{X} 1+0,385 \mathrm{X} 2+0,633 \mathrm{Y} 1$

Tabel 4.10. Koefisien Analisis Jalur Pengaruh Langsung dan Tidak Langsung

\begin{tabular}{|l|c|c|c|l|}
\hline \multicolumn{1}{|c|}{ Hasil analsis jalur } & Koefiisen jalur & Prob & Keterangan & Hipotesis \\
\hline Brand image $\rightarrow$ minat beli & 0,413 & 0,000 & signifikan & H1 diterima \\
\hline Sikap konsumen $\rightarrow$ minat beli & 0,371 & 0,000 & signifikan & H2 diterima \\
\hline Brand image $\rightarrow$ kep pembelian & 0,432 & 0,000 & signifikan & H3 diterima \\
\hline Sikap konsumen $\rightarrow$ kep pembelian & 0,385 & 0,000 & signifikan & H4 diterima \\
\hline minat beli $\rightarrow$ kep pembelian & 0,633 & 0,000 & signifikan & H5 diterima \\
\hline
\end{tabular}

Berdasarkan tabel 4.10 dapat dijelaskan hasil pengujian hipotesis sebagai berikut :

1. Hipotesis pertama (H1) menyatakan brand image berpengaruh terhadap minat beli. Nilai probabilitas error jalur nilai brand image berpengaruh terhadap minat beli sebesar 0,000 $<$ taraf signifkansi $(\alpha) 0,05$. Hasil analisis ini menunjukkan bahwa hipotesis pertama $(\mathrm{H} 1)$ yang menyatakan brand image berpengaruh terhadap minat beli diterima. Nilai koefisien jalur sebesar 0,413 menunjukka bahwa pengaruh brand image terhadap minat beli sebesar 0,413 .

2. Hipotesis pertama $(\mathrm{H} 2)$ menyatakan sikap konsumen berpengaruh terhadap minat beli. Nilai probabilitas error jalur nilai sikap konsumen berpengaruh terhadap minat beli sebesar $0,000<$ taraf signifkansi $(\alpha) 0,05$. Hasil analisis ini menunjukkan bahwa hipotesis kedua (H2) yang menyatakan sikap konsumen berpengaruh terhadap minat beli diterima. Nilai koefisien jalur sebesar 0,371 menunjukkan bahwa pengaruh sikap konsume terhadap minat beli sebesar 0,371 . 
3. Hipotesis ketiga (H3) menyatakan brand image berpengaruh terhadap keputusan pembelian. Nilai probabilitas error jalur brand image berpengaruh terhadap keputusan pembelian sebesar $0,000<$ taraf signifkansi $(\alpha) 0,05$. Hasil analisis ini menunjukkan bahwa hipotesis kedua (H2) yang menyatakan sikap konsumen berpengaruh terhadap minat beli diterima. Nilai koefisien jalur sebesar 0,432 menunjukkan bahwa pengaruh sikap konsume terhadap keputusan pembelian sebesar 0,432.

4. Hipotesis keempat (H4) menyatakan sikap konsume berpengaruh terhadap keputusan pembelian. Nilai probabilitas error jalur brand image berpengaruh terhadap keputusan pembelian sebesar $0,000<$ taraf signifkansi $(\alpha) 0,05$. Hasil analisis ini menunjukkan bahwa hipotesis keempat (H4) yang menyatakan sikap konsumen berpengaruh terhadap keputusan pembelian diterima. Nilai koefisien jalur sebesar 0,385 menunjukkan bahwa pengaruh sikap konsume terhadap keputusan pembelian sebesar 0,385.

5. Hipotesis kelima (H5) menyatakan minat beli berpengaruh terhadap keputusan pembelian. Nilai probabilitas error jalur minat beli berpengaruh terhadap keputusan pembelian sebesar $0,000<$ taraf signifkansi $(\alpha) 0,05$. Hasil analisis ini menunjukkan bahwa hipotesis kelima (H5) yang menyatakan minat beli berpengaruh terhadap keputusan pembelian diterima. Nilai koefisien jalur sebesar 0,633 menunjukkan bahwa pengaruh minat beli terhadap keputusan pembelian sebesar 0,633.

\section{Kesimpulan dan Saran}

1. Brand Image memiliki pengaruh positif dan signifikan terhadap minat beli. Hal ini berarti semakin baik brand image sebuah produk batik, maka akan semakin tinggi pula minat beli konsumen terhadap batik di Sidoarjo tersebut. Begitu juga sebaliknya jika brand image semakin rendah maka minat beli juga akan menurun.

2. Sikap konsumen memiliki pengaruh positif dan signifikan terhadap minat beli. Hal ini berarti semakin baik sikap konsumen sebuah produk batik, maka akan semakin tinggi pula minat beli konsumen terhadap batik di Sidoarjo tersebut. Begitu juga sebaliknya jika sikap konsumen semakin rendah maka minat beli juga akan menurun.

3. Brand Image memiliki pengaruh positif dan signifikan terhadap keputusan pembelian. Hal ini berarti semakin baik brand image sebuah produk batik, maka akan memudahkan konsumen mengambil keputusan dalam membeli batik di Sidoarjo tersebut. Begitu juga sebaliknya jika brand image yang dimiliki semakin rendah akan membuat konsumen enggan untuk membeli batik tersebut. 
4. Sikap konsumen berpengaruh secara signifikan terhadap keputusan pembelian. Hal ini berarti semakin baik sikap konsumen, mempengaruhi konsumen dalam membeli produk batik di Sidoarjo. Sikap positif yang dimiliki terhadap batik di Sidoarjo tidak mempengaruhi konsumen untuk memutuskan membeli.

5. Minat beli memiliki pengaruh positif dan signifikan terhadap keputusan pembelian. Hal ini berarti semakin tinggi minat beli konsumen terhadap produk batik di Sidoarjo, maka pengambilan keputusan konsumen semakin meningkat dalam membeli batik di Sidoarjo tersebut. Begitu juga sebaliknya jika minat beli rendah akan membuat konsumen enggan untuk membeli batik tersebut.

6. Brand Image memiliki pengaruh positif dan signifikan terhadap keputusan pembelian yang dimediasi minat beli. Hal ini berarti jika brand image semakin baik maka minat beli dan pengambilan keputusan pembelian konsumen juga meningkat. Begitu juga sebaliknya jika brand image semakin rendah maka minat beli dan pengambilan keputusan pembelian juga akan menurun. Total pengaruh tidak langsung brand image terhadap keputusan pembelian melalui minat beli lebih besar dari pengaruh langsung brand image terhadap keputusan pembelian, sehingga minat beli dapat menjadi variabel mediasi.

7. Sikap konsumen memiliki pengaruh positif dan signifikan terhadap keputusan pembelian yang dimediasi minat beli. Hal ini berarti jika sikap konsumen semakin baik maka minat beli dan pengambilan keputusan pembelian konsumen juga meningkat. Begitu juga sebaliknya jika sikap konsumen semakin rendah maka minat beli dan pengambilan keputusan pembelian juga akan menurun. Total pengaruh tidak langsung sikap konsumen terhadap keputusan pembelian melalui minat beli lebih besar dari pengaruh langsung sikap konsumen terhadap keputusan pembelian, sehingga minat beli dapat menjadi variabel mediasi.

\subsection{Saran}

Dalam penelitian ini, penulis juga memberikan saran kepada pihak-pihak yang berkepentingan terhadap penelitian ini antara lain :

1. Bagi pemasar batik Jetis di Sidoarjo

a. Berkaitan dengan citra dari batik Jetis di Sidoarjo, hendaknya mengembangkan inovasi produk, supaya Image dari batik di Sidoarjo itu positif. Semakin baik image atau semakin besar kesadaran konsumen akan merek (awareness) akan mendorong potensial konsumen untuk membeli produk batik karena konsumen telah lebih mengenal produk batik suatu merek tersebut. 
b. Berkaitan dengan pilihan penyalur atau tempat, hendaknya perbaikan dilakukan terutama pada sektor tata ruang untuk kios-kios, lingkungan kantin yang rapi dan bersih akan lebih mencitrakan bahwa obyek ini tertib dan indah. Kemudian membuat fasilitas yang memadai dan layak supaya pengunjung nyaman pada saat berbelanja.

c. Berkaitan dengan minimnya informasi tentang batik, hendaknya menyelenggarakan event batik atau festival batik yang ada di Sidoarjo agar konsumen mengetahui dan menyukai produk batik serta melakukan pembelian batik tersebut.

\section{DAFTAR PUSTAKA}

Amanah, Dita. 2011. Pengaruh Promosi dan Brand Image (Citra Produk) terhadap Loyalitas Pembelian Pepsodent di Ramayana Plaza Jalan Aksara Medan. Jurnal Keuangan dan Bisnis, volume 3 No 3, November 2011.

Arista, E. Desi \& Sri Rahayu Triatuti. 2011. Analisis Pengaruh Iklan, Kepercayaan Merek dan Citra Merek terhadap Minat Beli Konsumen. Fakultas Ekonomika dan Bisnis. Universitas Diponegoro.

Bhaduri, Gargi. 2011. "Trust/Distrust, Perceived Quality, Perceived Price, And Apparel Purchase Intention". Thesis. Unites State of America: Faculty of Graduate School Universitas Missouri.

Febiana, Dina,. Srikandi Kumadji \&Sunarti. 2014. Pengaruh Word of Mouth terhadap Minat Beli serta Dampaknya pada Keputusan Pembelian (Survei pada Pengunjung yang Melakukan Pembelian pada Biker's Resto dan Cafe di Kota Malang). Jurnal Administrasi Bisnis (JAB)|Vol. 16 No. 1 November 2014.

Keller, Kevin Lane, 1998, Strategic Brands Management: Building, Measuring, And Managing Brand Equity, New Jersey: PrenticeHall Inc.

Kotler, Philip. 2005. Manajemen Pemasaran jilid I, Edisi Kesebelas. Jakarta : Indeks. 2006. Manajemen Pemasaran Jilid II. Jakarta : PT Indeks.

Kotler Philip \& Armstrong. 2008. Principles of Marketing Kotler \& Amstrong Pearson Education, Inc, New Jersey.

Kotler Philip \& Kevin Lane Keller. 2008. Manajemen Pemasaran, Edisi Ketigabelas, Jilid Dua. Jakarta : Erlangga.

Mahendrayasa, Andhanu Catur.,Srikandi Kumadji \&Yusri Abdillah. 2014. Pengaruh Word of Mouth terhadap Minat Beli serta Dampaknya pada Keputusan Pembelian. Fakultas Ilmu Administrasi. Universitas Brawijaya.

Mardiastika, Ema. 2012. Analisis Pengaruh Kualitas Layanan, Kualitas Film, Efek Komunitas dan Persepsi Harga terhadap Sikap Menonton dan Implikasinya Terhadap Minat (Studi Kasus Pada Penonton Bioskop Entertaiment Plaza Semarang Mahasiswa 
Fakultas Ekonomika dan Bisnis UNDIP Semarang).Skripsi. Semarang : Universitas Diponegoro.

Rizan, Mohammad,. Basrah Saidani \&Yusiyana Sari. 2012. Pengaruh Brand Image dan Brand Trust terhadap Brand Loyalty Teh Botol Sosro (Survei Konsumen Teh Botol Sosro di Food Court ITC Cempaka Mas, Jakarta timur). Jurnal Riset Manajemen Sains Indonesia (JRMSI). Vol. 3, No. 1, 2012.

Schiffman, Leon dan Leslie Lazar Kanuk. 2010. Perilaku Konsumen, Edisi 7. Jakarta: Indeks.

Setiadi, Nugroho J. 2003.Prilaku Konsumen Konsep dan Implikasi Untuk Strategi dan Penelitian Pemasaran, Edisi Pertama, Cetakan I. Bogor : Kencana.

Simamora, Bilson \& Johanes Lim. 2002. Aura Merek : 7 Langkah Membangun Merek yang Kuat. Jakarta : Gramedia Pustaka Utama.

Sumarwan, Ujang. 2011. Perilaku Konsumen : Teori dan Penerapannya Dalam Pemasaran. Bogor: Ghalia Indonesia.

Suryani, Tatik. 2008. Perilaku Konsumen, Implikasi Pada Strategi Pemasaran, Edisi Pertama, Cetakan Pertama. Jakarta : Graha Ilmu.

Iwan, Cindy Yuanita. 2013. Pengaruh Sikap terhadap Green Advertising pada Brand Image The Body Shop antara Konsumen Domestik dan Asing. Jurnal JIBEKA Volume 7, No 3, Agustus 2013.

Ferdinand, Augusty. 2011. Metode Penelitian Manajemen: Pedoman Penelitian untuk Penulisan Skripsi, Tesis, dan Disertasi Ilmu Manajemen. Semarang: Badan Penerbit Universitas Diponegoro. 